\title{
Nomogram for Predicting COVID-19 Disease Progression Based on Single-Center Data: Observational Study and Model Development
}

Tao Fan*, PhD, MD; Bo Hao*, PhD, MD; Shuo Yang", MD; Bo Shen, PhD, MD; Zhixin Huang ${ }^{*}, \mathrm{PhD}$, MD; Zilong Lu, MD; Rui Xiong, MD; Xiaokang Shen, MD; Wenyang Jiang, PhD, MD; Lin Zhang, MD; Donghang Li, MD; Ruyuan He, MD, PhD; Heng Meng, MD, PhD; Weichen Lin, MD, PhD; Haojie Feng, MD; Qing Geng, PhD, MD

Renmin Hospital, Wuhan University, Wuhan, China

*these authors contributed equally

Corresponding Author:

Qing Geng, PhD, MD

Renmin Hospital

Wuhan University

238 Jiefang Road

Wuhan, 430060

China

Phone: 2788041911880419

Email: gengqingwhu@whu.edu.cn

\section{Abstract}

Background: In late December 2019, a pneumonia caused by SARS-CoV-2 was first reported in Wuhan and spread worldwide rapidly. Currently, no specific medicine is available to treat infection with COVID-19.

Objective: The aims of this study were to summarize the epidemiological and clinical characteristics of 175 patients with SARS-CoV-2 infection who were hospitalized in Renmin Hospital of Wuhan University from January 1 to January 31, 2020, and to establish a tool to identify potential critical patients with COVID-19 and help clinical physicians prevent progression of this disease.

Methods: In this retrospective study, clinical characteristics of 175 confirmed COVID-19 cases were collected and analyzed. Univariate analysis and least absolute shrinkage and selection operator (LASSO) regression were used to select variables. Multivariate analysis was applied to identify independent risk factors in COVID-19 progression. We established a nomogram to evaluate the probability of progression of the condition of a patient with COVID-19 to severe within three weeks of disease onset. The nomogram was verified using calibration curves and receiver operating characteristic curves.

Results: A total of 18 variables were considered to be risk factors after the univariate regression analysis of the laboratory parameters $(P<.05)$, and LASSO regression analysis screened out 10 risk factors for further study. The six independent risk factors revealed by multivariate Cox regression were age (OR 1.035, 95\% CI 1.017-1.054; $P<.001)$, CK level (OR 1.002, 95\% CI $1.0003-1.0039 ; P=.02$ ), CD4 count (OR 0.995, 95\% CI 0.992-0.998; $P=.002$ ), CD8 \% (OR 1.007, 95\% CI 1.004-1.012, $P<.001$ ), CD8 count (OR 0.881, 95\% CI 0.835-0.931; $P<.001$ ), and C3 count (OR 6.93, 95\% CI 1.945-24.691; $P=.003$ ). The areas under the curve of the prediction model for 0.5 -week, 1 -week, 2-week and 3-week nonsevere probability were $0.721,0.742,0.87$, and 0.832 , respectively. The calibration curves showed that the model had good prediction ability within three weeks of disease onset.

Conclusions: This study presents a predictive nomogram of critical patients with COVID-19 based on LASSO and Cox regression analysis. Clinical use of the nomogram may enable timely detection of potential critical patients with COVID-19 and instruct clinicians to administer early intervention to these patients to prevent the disease from worsening.

(JMIR Med Inform 2020;8(9):e19588) doi: 10.2196/19588

\section{KEYWORDS}

coronavirus disease 2019; COVID-19; risk factors; nomogram 


\section{Introduction}

\section{Background}

COVID-19 is a respiratory illness that is caused by the novel virus SARS-CoV-2; it was first reported in December 2019 in Wuhan, Hubei Province, China [1-5]. Although governments of countries worldwide have called for and taken relevant measures to stop the spread of the disease, the epidemic has not been effectively controlled [6-8]. Symptoms of COVID-19 range from mild cough to pneumonia; patients may even be asymptomatic [3,9]. There is evidence that this disease can be spread from person to person [10]. Whole genome sequencing showed that SARS-CoV-2 is a beta coronavirus that is similar to human severe acute respiratory syndrome coronavirus (SARS-CoV) and Middle East respiratory syndrome coronavirus (MERS-CoV). This new coronavirus evolved from SARS-CoV and MERS-CoV and requires enhanced surveillance and further investigation [11]. Like several other coronaviruses, SARS-CoV-2 initially causes mild or moderate symptoms in most patients $[12,13]$. To date, only a small percentage of patients with SARS-CoV-2 infection have developed severe pneumonia. Although the average incubation period of SARS-CoV-2 in the human body is 14 days, some patients progress rapidly to respiratory failure once they become infected. Recognition of the risk factors that promote COVID-19 progression and early intervention of this disease may prevent its exacerbation. Understanding these factors is also very important to reduce the proportion of critically ill patients and to improve the cure rate.

\section{Study Goals}

The aim of this study was to summarize the epidemiological and clinical characteristics of 175 patients with SARS-CoV-2 infection who were hospitalized in Renmin Hospital of Wuhan
University from January 1 to January 31,2020 . The study also aimed to explore the independent risk factors in COVID-19 progression and accurately assess the incidence of severe SARS-CoV-2 infection. In addition, a new risk-predictive model was established to screen out potential critical patients for early intervention.

\section{Methods}

\section{Patient Recruitment}

For this retrospective single-center study, 175 patients who were hospitalized from January 1 to January 31, 2020, in Renmin Hospital of Wuhan University were enrolled. Patients who were hospitalized for less than 24 hours or who lacked detailed laboratory test results were excluded (Figure 1). All the patients in this study were diagnosed according to the World Health Organization (WHO) interim guidance [14]. All the patients with COVID-19 were diagnosed using a reverse transcriptase-polymerase chain reaction (RT-PCR) assay for SARS-CoV-2 according to the Pneumonitis Diagnosis and Treatment Plan for SARS-CoV-2 Infection (Trial Version 5) issued by the National Health Commission of the People's Republic of China (NHCPRC). The test was performed using specific steps described previously [9]. All the clinical features, radiological characteristics, clinical laboratory results, and outcome data of the 175 patients were obtained from electronic medical records. Detailed patient information was collected, including past medical history, current medical history, laboratory findings, imaging data, treatment measures, symptoms, signs, and immune function test results. Follow-up was initiated from suspicion of infection or confirmed diagnosis to the time when the patient's condition became severe to the time of discharge or to January 31, 2020. We recorded the baselines of these tests, with the first value being within three days of onset admission. 
Figure 1. Study flowchart. LASSO: least absolute shrinkage and selection operator.

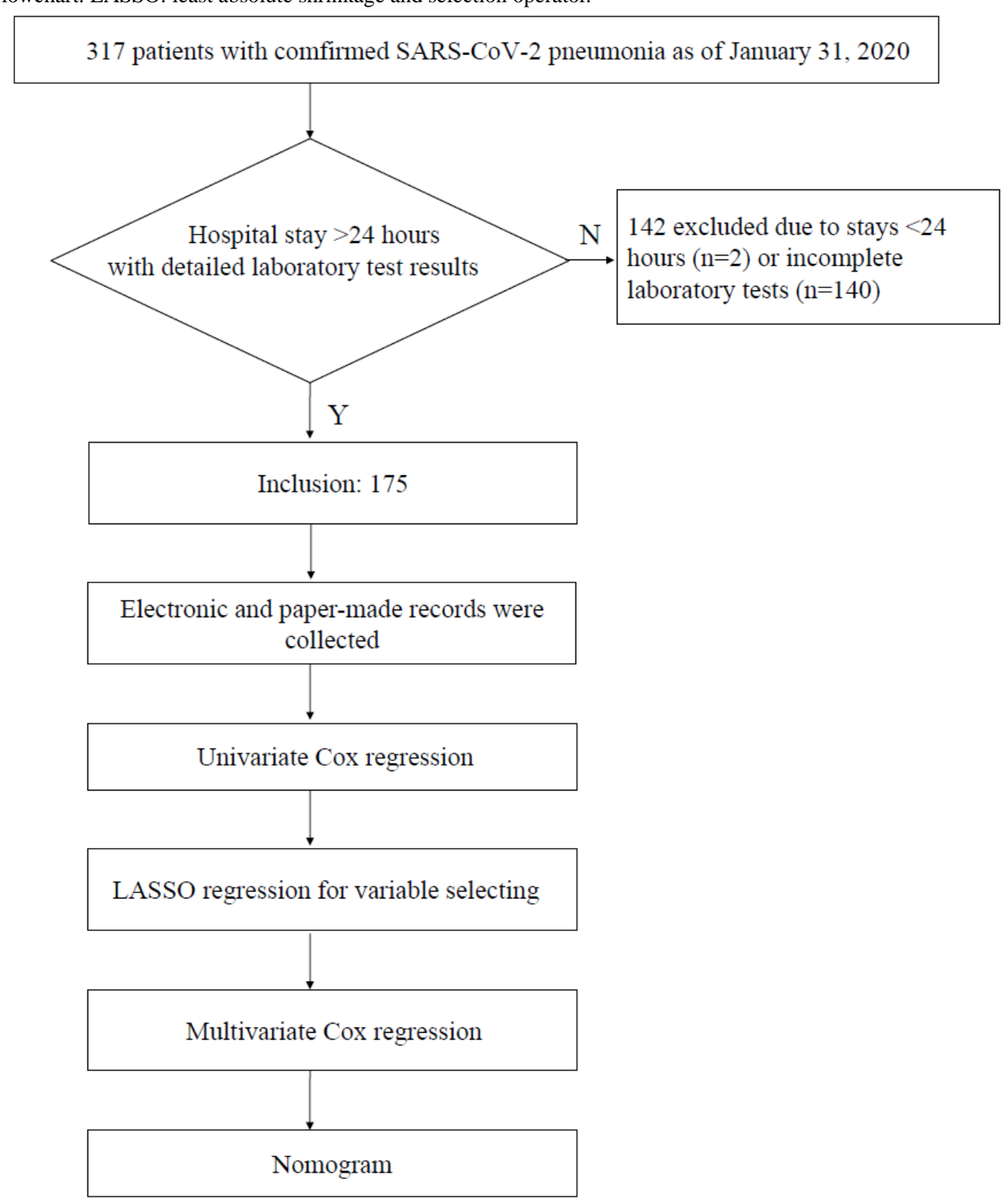

\section{Statistical Analysis}

Frequency rates were used to describe categorical variables, and means were used to describe continuous variables. Differences between groups were tested using the chi-square test, $t$ test, or Mann-Whitney U test. Univariate analysis, least absolute shrinkage and selection operator (LASSO) regression, and multivariate Cox regression were used to screen for independent risk factors. The statistical analyses were performed using GraphPad Prism 8 (GraphPad Software). Nomogram, calibration, and receiver operating characteristic (ROC) curves were established using $\mathrm{R}$ version 3.6.1 (R Project). The risk score was calculated using multivariate Cox regression. The cutoff values of independent risk factors were based on the maximum Youden index. A 2 -sided $\alpha<.05$ was considered to indicate statistical significance.

\section{Results}

\section{Patient Characteristics}

All 175 patients in this study were confirmed to be infected with SARS-CoV-2. The average age of the 175 patients was 46.9 years (SD 17.33). Severe or critical patients were significantly older than mild or moderate patients $(P<.001)$. Critical patients had a wider range of lung lesions than milder patients $(P<.001)$. Chest tightness was more common in severe or critical patients than in mild or moderate patients $(P=.001)$. Table 1 shows comparisons of the significant characteristics between the two groups of patients enrolled in the study $(P<.05)$. 
Table 1. Baseline characteristics of the patients infected with SARS-CoV-2 $(\mathrm{N}=175)$.

\begin{tabular}{|c|c|c|c|c|c|}
\hline \multirow[t]{2}{*}{ Participant characteristics } & \multicolumn{4}{|c|}{ Values by disease severity } & \multirow[t]{2}{*}{$P$ value } \\
\hline & $\begin{array}{l}\text { Mild } \\
(\mathrm{n}=27)\end{array}$ & $\begin{array}{l}\text { Moderate } \\
(n=72)\end{array}$ & $\begin{array}{l}\text { Severe } \\
(\mathrm{n}=18)\end{array}$ & $\begin{array}{l}\text { Critical } \\
(\mathrm{n}=58)\end{array}$ & \\
\hline Sex, n (\%) & & & & & .64 \\
\hline Female & $13(48.1)$ & $41(56.9)$ & $11(61.1)$ & $28(48.3)$ & \\
\hline Male & $14(51.9)$ & $31(43.1)$ & $7(38.9)$ & $30(51.7)$ & \\
\hline Age (years), median (IQR) & $31(29-42)$ & $35(30-50.75)$ & $51(37.75-61)$ & $62(47-71)$ & $<.001$ \\
\hline Age (years), n (\%) & & & & & $<.001$ \\
\hline$\leq 30$ & $11(40.7)$ & $21(29.2)$ & $1(5.6)$ & $3(5.2)$ & \\
\hline $31-40$ & $8(29.6)$ & $25(34.7)$ & $4(22.2)$ & $7(12.1)$ & \\
\hline $41-50$ & $4(14.8)$ & $8(11.1)$ & $4(22.2)$ & $6(10.3)$ & \\
\hline $51-60$ & $1(3.7)$ & $13(18.1)$ & $5(27.8)$ & $10(17.2)$ & \\
\hline$>60$ & $3(11.1)$ & $5(6.9)$ & $4(22.2)$ & $32(55.2)$ & \\
\hline Computed tomography scan, n (\%) & & & & & $<.001$ \\
\hline Normal & $27(100)$ & $0(0)$ & $0(0)$ & $0(0)$ & \\
\hline One lobe infected & $0(0)$ & $25(34.7)$ & $6(33.3)$ & $5(8.6)$ & \\
\hline More than one lobe infected & $0(0)$ & $47(65.3)$ & $12(66.7)$ & $53(91.4)$ & \\
\hline Fever, $\mathbf{n}(\%)$ & & & & & .01 \\
\hline Yes & $17(63)$ & $43(59.7)$ & $14(77.8)$ & $49(84.5)$ & \\
\hline No & $10(37)$ & $29(40.3)$ & $4(22.2)$ & $9(15.5)$ & \\
\hline Dry cough, n (\%) & & & & & .07 \\
\hline Yes & $2(7.4)$ & $11(15.3)$ & $3(16.7)$ & $17(29.3)$ & \\
\hline No & $25(92.6)$ & $61(84.7)$ & $15(83.3)$ & $41(70.7)$ & \\
\hline Expectoration, n (\%) & & & & & .007 \\
\hline Yes & $5(18.5)$ & $28(38.9)$ & $10(55.6)$ & $33(56.9)$ & \\
\hline No & $22(81.5)$ & $44(61.1)$ & $8(44.4)$ & $25(43.1)$ & \\
\hline Pharyngalgia, n (\%) & & & & & .25 \\
\hline Yes & $4(14.8)$ & $11(15.3)$ & $0(0)$ & $5(8.6)$ & \\
\hline No & $23(85.2)$ & $61(84.7)$ & $18(100)$ & $53(91.4)$ & \\
\hline Chest tightness, n (\%) & & & & & .001 \\
\hline Yes & $6(22.2)$ & $8(11.1)$ & $7(38.9)$ & $23(39.7)$ & \\
\hline No & $21(77.8)$ & $64(88.9)$ & $11(61.1)$ & $35(60.4)$ & \\
\hline Myalgia, n (\%) & & & & & .80 \\
\hline Yes & $4(14.8)$ & $6(8.3)$ & $2(11.1)$ & $7(12.1)$ & \\
\hline No & $23(85.2)$ & $66(91.7)$ & $16(88.9)$ & $51(87.9)$ & \\
\hline Fatigue, n (\%) & & & & & .62 \\
\hline Yes & $8(29.6)$ & $18(25)$ & $3(16.7)$ & $11(19)$ & \\
\hline No & $19(70.4)$ & $54(75)$ & $15(83.3)$ & $47(81)$ & \\
\hline Diarrhea, n (\%) & & & & & .55 \\
\hline Yes & $3(11.1)$ & $5(6.9)$ & $0(0)$ & $4(6.9)$ & \\
\hline No & $24(88.9)$ & $67(93.1)$ & $18(100)$ & $54(93.1)$ & \\
\hline Headache, n (\%) & & & & & .08 \\
\hline Yes & $6(22.2)$ & $11(15.3)$ & $1(5.6)$ & $3(5.2)$ & \\
\hline
\end{tabular}




\begin{tabular}{clll}
\hline Participant characteristics & Values by disease severity & & Moderate \\
& $\begin{array}{l}\text { Mild } \\
(\mathrm{n}=27)\end{array}$ & $\begin{array}{l}\text { Severe } \\
(\mathrm{n}=72)\end{array}$ & $\begin{array}{l}\text { Critical } \\
(\mathrm{n}=58)\end{array}$ \\
\hline No & $21(77.8)$ & $61(84.7)$ & $17(94.4)$
\end{tabular}

\section{Laboratory Parameters}

The baseline laboratory tests are shown in Table 2. As the patients' conditions worsened, their lymphocyte counts significantly decreased, while their C-reactive protein, lactate dehydrogenase, and creatine kinase (CK) levels increased significantly (Table 2). More importantly, the CD3 (count and ratio), CD4 (count and ratio), CD8 (count and ratio), and CD19 (count and ratio) values of severe or critical patients were lower than those of the mild or moderate patients (Table 2). In addition, severe or critical patients had higher IgG levels than mild or moderate patients (Table 2). 
Table 2. Laboratory findings of patients infected with SARS-CoV-2 on admission to hospital (N=175).

\begin{tabular}{|c|c|c|c|c|c|c|}
\hline \multirow[t]{2}{*}{ Variable } & \multirow{2}{*}{$\begin{array}{l}\text { Normal } \\
\text { range }\end{array}$} & \multicolumn{4}{|c|}{ Values by disease severity, mean $(95 \% \mathrm{CI})$} & \multirow[t]{2}{*}{$P$ value } \\
\hline & & Mild & Moderate & Severe & Critical & \\
\hline $\begin{array}{l}\text { White blood cell count, } \\
\times 10^{9} / \mathrm{L}\end{array}$ & $3.5-9.5$ & $5.16(4.47$ to 5.86$)$ & 4.73 (4.39 to 5.07$)$ & 5.37 (4.1 to 6.64$)$ & $5.22(4.69$ to 5.75$)$ & .35 \\
\hline Neutrophil count, $\times 10^{9} / \mathrm{L}$ & $1.8-6.3$ & $2.98(2.35$ to 3.61$)$ & 2.62 (2.38 to 2.87$)$ & 3.95 (2.64 to 5.26$)$ & 3.83 (3.31 to 4.35$)$ & $<.001$ \\
\hline Lymphocyte count, $\times 10^{9} / \mathrm{L}$ & $1.1-3.2$ & 1.55 (1.33 to 1.77$)$ & $1.58(1.41$ to 1.74$)$ & $1.02(0.78$ to 1.26$)$ & $0.96(0.82$ to 1.09$)$ & $<.001$ \\
\hline Platelet count, $\times 10^{9} / \mathrm{L}$ & $125-350$ & $\begin{array}{l}209.2(182.7 \text { to } \\
235.7)\end{array}$ & $\begin{array}{l}208.1(194.4 \text { to } \\
221.7)\end{array}$ & $\begin{array}{l}211.9 \text { (169.9 to } \\
253.9)\end{array}$ & $\begin{array}{l}186.9(171.0 \text { to } \\
202.7)\end{array}$ & .19 \\
\hline C-reactive protein, $\mathrm{mg} / \mathrm{L}$ & $0-5$ & $4.99(1.02$ to 8.95$)$ & $\begin{array}{l}9.21(5.87 \text { to } \\
12.55)\end{array}$ & 31.1 (13.98 to 48.22$)$ & $\begin{array}{l}43.24(32.70 \text { to } \\
53.77)\end{array}$ & $<.001$ \\
\hline $\begin{array}{l}\text { Alanine aminotransferase, } \\
\text { U/L }\end{array}$ & $9-50$ & $\begin{array}{l}24.93(15.78 \text { to } \\
34.07)\end{array}$ & $\begin{array}{l}22.15(17.26 \text { to } \\
27.05)\end{array}$ & $\begin{array}{l}29.67(20.58 \text { to } \\
38.75)\end{array}$ & $\begin{array}{l}28.64(23.13 \text { to } \\
34.15)\end{array}$ & .28 \\
\hline $\begin{array}{l}\text { Aspartate aminotrans- } \\
\text { ferase, U/L }\end{array}$ & $15-40$ & $\begin{array}{l}24.85 \text { (20.06 to } \\
29.64)\end{array}$ & $\begin{array}{l}22.85(20.40 \text { to } \\
25.30)\end{array}$ & $\begin{array}{l}29.61(22.93 \text { to } \\
36.29)\end{array}$ & $\begin{array}{l}33.24(28.66 \text { to } \\
37.82)\end{array}$ & $<.001$ \\
\hline Urea, mmol/L & $3.1-8.0$ & $3.71(3.11$ to 4.3$)$ & 4.05 (3.79 to 4.3$)$ & 6.17 (4.6 to 7.74$)$ & 5.74 (4.36 to 7.12$)$ & .003 \\
\hline Creatinine, $\mu \mathrm{mol} / \mathrm{L}$ & $57-97$ & $\begin{array}{l}52.41(46.13 \text { to } \\
58.68)\end{array}$ & $\begin{array}{l}54.44(51.71 \text { to } \\
57.18)\end{array}$ & $\begin{array}{l}68.06(54.75 \text { to } \\
81.36)\end{array}$ & $\begin{array}{l}94.14(50.26 \text { to } \\
138.0)\end{array}$ & .1 \\
\hline $\begin{array}{l}\text { Lactate dehydrogenase, } \\
\text { U/L }\end{array}$ & $120-250$ & $\begin{array}{l}186.2(165.1 \text { to } \\
207.2)\end{array}$ & $\begin{array}{l}193.8(182.4 \text { to } \\
205.2)\end{array}$ & $\begin{array}{l}242.1(201.1 \text { to } \\
283.0)\end{array}$ & $\begin{array}{l}294.1(262.7 \text { to } \\
325.5)\end{array}$ & $<.001$ \\
\hline Creatine kinase, U/L & $50-310$ & $\begin{array}{l}64.96(24.26 \text { to } \\
105.7)\end{array}$ & $\begin{array}{l}71.03(58.94 \text { to } \\
83.11)\end{array}$ & $\begin{array}{l}87.67 \text { ( } 45.81 \text { to } \\
129.5)\end{array}$ & $\begin{array}{l}123.4(83.10 \text { to } \\
163.7)\end{array}$ & .03 \\
\hline CD3 $(\%)$ & $56-86$ & $\begin{array}{l}72.15(68.45 \text { to } \\
75.84)\end{array}$ & $\begin{array}{l}70.8(68.62 \text { to } \\
72.99)\end{array}$ & $\begin{array}{l}67.68(61.38 \text { to } \\
73.99)\end{array}$ & $\begin{array}{l}58.19(54.36 \text { to } \\
62.03)\end{array}$ & $<.001$ \\
\hline CD3 count, $/ \mu \mathrm{L}$ & $723-2737$ & $\begin{array}{l}1124(923.0 \text { to } \\
1326)\end{array}$ & $\begin{array}{l}1036(933.0 \text { to } \\
1140)\end{array}$ & $\begin{array}{l}658.4(465.9 \text { to } \\
851.0)\end{array}$ & $\begin{array}{l}577.1(460.1 \text { to } \\
694.1)\end{array}$ & $<.001$ \\
\hline CD4 (\%) & $33-58$ & $\begin{array}{l}41.71(38.81 \text { to } \\
44.61)\end{array}$ & $\begin{array}{l}41.19(39.18 \text { to } \\
43.20)\end{array}$ & $\begin{array}{l}41.85(37.44 \text { to } \\
46.26)\end{array}$ & $\begin{array}{l}31.91(29.23 \text { to } \\
34.60)\end{array}$ & $<.001$ \\
\hline CD4 count, $/ \mu \mathrm{L}$ & $404-1612$ & $\begin{array}{l}669.9(573.6 \text { to } \\
766.3)\end{array}$ & $\begin{array}{l}610.8(544.8 \text { to } \\
676.7)\end{array}$ & $\begin{array}{l}402.7(288.5 \text { to } \\
517.0)\end{array}$ & 315 (247.2 to 382.7$)$ & $<.001$ \\
\hline CD8 (\%) & $13-39$ & $\begin{array}{l}27.06(24.62 \text { to } \\
29.51)\end{array}$ & $\begin{array}{l}25.75(24.41 \text { to } \\
27.08)\end{array}$ & $\begin{array}{l}22.64(18.63 \text { to } \\
26.64)\end{array}$ & $\begin{array}{l}23.98(20.97 \text { to } \\
26.98)\end{array}$ & .21 \\
\hline CD8 count, $/ \mu \mathrm{L}$ & $220-1129$ & $\begin{array}{l}444.3(355.1 \text { to } \\
533.5)\end{array}$ & $\begin{array}{l}369.8(328.7 \text { to } \\
410.8)\end{array}$ & $\begin{array}{l}227.6(151.7 \text { to } \\
303.4)\end{array}$ & $\begin{array}{l}237.9 \text { (183.9 to } \\
291.9)\end{array}$ & $<.001$ \\
\hline $\mathrm{CD} 4 / \mathrm{CD} 8$ ratio & $0.9-2.0$ & $1.64(1.43$ to 1.85$)$ & 1.93 (1.46 to 2.4$)$ & $2.55(1.28$ to 3.81$)$ & 1.63 (1.38 to 1.87$)$ & .17 \\
\hline CD19 (\%) & $5-22$ & $\begin{array}{l}14.04(11.53 \text { to } \\
16.55)\end{array}$ & $\begin{array}{l}13.21(12.00 \text { to } \\
14.43)\end{array}$ & $\begin{array}{l}21.82(15.30 \text { to } \\
28.34)\end{array}$ & $\begin{array}{l}15.46(13.39 \text { to } \\
17.54)\end{array}$ & $<.001$ \\
\hline CD19 count, $/ \mu \mathrm{L}$ & $80-616$ & $\begin{array}{l}210(169.4 \text { to } \\
250.5)\end{array}$ & $\begin{array}{l}197.1(163.0 \text { to } \\
231.2)\end{array}$ & $\begin{array}{l}178.2(120.0 \text { to } \\
236.4)\end{array}$ & 129 (108.4 to 149.6$)$ & .004 \\
\hline CD16+56 (\%) & $5-26$ & $\begin{array}{l}17.66(3.458 \text { to } \\
31.86)\end{array}$ & $\begin{array}{l}13.09(11.22 \text { to } \\
14.97)\end{array}$ & $8.92(6.227$ to 11.61$)$ & $\begin{array}{l}23.85(20.21 \text { to } \\
27.49)\end{array}$ & $<.001$ \\
\hline CD16+56 count, $/ \mu \mathrm{L}$ & $84-724$ & $\begin{array}{l}161.3(82.20 \text { to } \\
240.3)\end{array}$ & $\begin{array}{l}183.5 \text { (150.4 to } \\
216.5)\end{array}$ & $\begin{array}{l}82.78(55.13 \text { to } \\
110.4)\end{array}$ & $190(154.7$ to 225.3$)$ & .04 \\
\hline $\mathrm{IgG}, \mathrm{g} / \mathrm{L}$ & $8-16$ & $\begin{array}{l}11.83(10.32 \text { to } \\
13.34)\end{array}$ & $\begin{array}{l}11.81 \text { (11.01 to } \\
12.62)\end{array}$ & $\begin{array}{l}18.08(15.44 \text { to } \\
20.73)\end{array}$ & $\begin{array}{l}13.79(12.64 \text { to } \\
14.93)\end{array}$ & $<.001$ \\
\hline $\operatorname{IgM}, g / L$ & $0.4-3.45$ & $1.19(1.03$ to 1.35$)$ & $1.2(1.07$ to 1.33$)$ & $1.08(0.74$ to 1.41$)$ & 1.13 (1.0 to 1.27$)$ & .79 \\
\hline $\operatorname{IgA}, \mathrm{g} / \mathrm{L}$ & $0.76-3.9$ & $1.9(1.55$ to 2.25$)$ & $\begin{array}{l}4.49(-0.42 \text { to } \\
9.39)\end{array}$ & $\begin{array}{l}1.83 \\
\text { (1.44 to } 2.22)\end{array}$ & $\begin{array}{l}2.23 \\
(1.94 \text { to } 2.52)\end{array}$ & .71 \\
\hline $\mathrm{IgE}, \mathrm{IU} / \mathrm{mL}$ & $<100$ & $\begin{array}{l}71.7(27.92 \text { to } \\
115.5)\end{array}$ & $\begin{array}{l}88.89 \text { (41.23 to } \\
136.6)\end{array}$ & $\begin{array}{l}59.83(8.444 \text { to } \\
111.2)\end{array}$ & 84.1 (54.48 to 113.7$)$ & .89 \\
\hline
\end{tabular}




\begin{tabular}{llllllll}
\hline Variable & $\begin{array}{l}\text { Normal } \\
\text { range }\end{array}$ & \multicolumn{2}{l}{ Values by disease severity, mean $(95 \%$ CI $)$} & & $P$ value \\
& & Mild & Moderate & Severe & Critical & \\
\hline Complement C3, g/L & $0.81-1.6$ & $0.78(0.72$ to 0.84$)$ & $0.83(0.79$ to 0.87$)$ & $0.89(0.81$ to 0.98$)$ & $0.88(0.82$ to 0.94$)$ & .09 \\
Complement $\mathrm{C} 4, \mathrm{~g} / \mathrm{L}$ & $0.1-0.4$ & $0.2(0.17$ to 0.23$)$ & $0.24(0.22$ to 0.27$)$ & $0.22(0.19$ to 0.25$)$ & $0.28(0.25$ to 0.31$)$ & .003 \\
\hline
\end{tabular}

\section{Screening for Independent Risk Factors and Constructing a Predictive Nomogram}

The 175 patients were divided into a Mild group and a Severe group according to disease severity. Patients with mild and moderate illness were included in the Mild Group (nonsevere illness), and patients with severe and critical illness were included in the Severe Group. A total of 18 variables were considered to be risk factors as revealed by the univariate analysis (Multimedia Appendix 1). We performed LASSO Cox regression to further select variables (Figure 2), followed by multivariate Cox regression analysis. Multimedia Appendix 2 shows the results of the multivariate analysis. With older age (odds ratio [OR] 1.035, 95\% CI 1.017-1.054); higher levels of blood CK (OR 1.002, 95\% CI 1.0003-1.0039), CD8 \% (OR $1.007,95 \%$ CI 1.004-1.012), and C3 (OR 6.93, 95\% CI 1.945-24.691); and lower levels of CD4 (OR 0.995, 95\% CI 0.992-0.998) and CD8 (OR 0.881, 95\% CI 0.835-0.931), a patient would be more likely to progress to severe disease within three weeks of disease onset.

Figure 2. (A) The $\log (\lambda)$ values of the 18 parameters as shown using least absolute shrinkage and selection operator (LASSO) coefficient profiles. (B) The most suitable $\log (\lambda)$ values for variable selection based on the LASSO Cox regression.

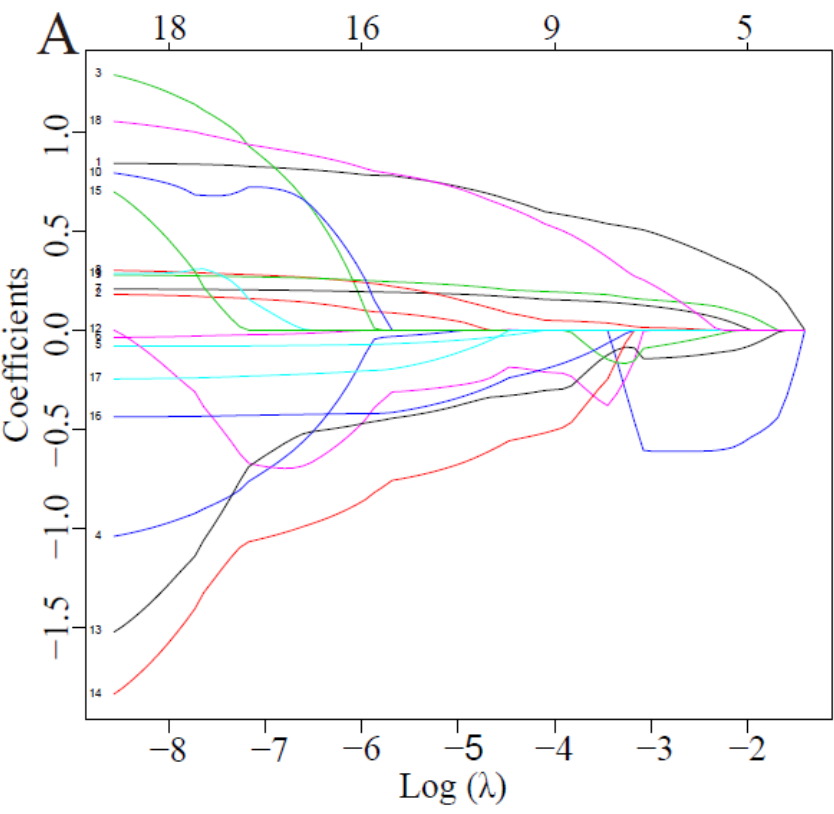

Figure 3 shows the nomogram of the multivariate Cox regression model. All independent risk factors have their own lines in the nomogram, with each receiving a point according to value. The total points are added and match the probability of COVID-19 progression. An example is shown in Multimedia Appendix 3, and the calibration curves are shown in Multimedia Appendix

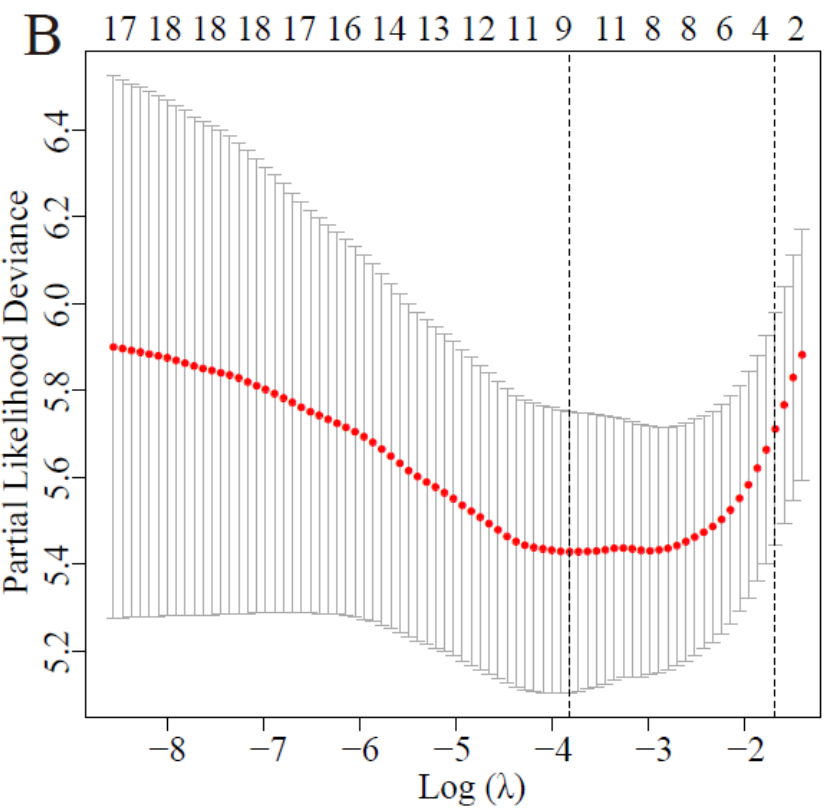

4. The apparent value is close to the ideal value, which indicates good predictive performance of the model. Multimedia Appendix 5 shows the areas under the ROC curves of the nomogram. The curves proved that this model obtained in the study had good predictive performance for COVID-19 progression within three weeks. 
Figure 3. Establishment of the nomogram based on the six independent risk factors resulting from multivariate Cox regression to predict the 0.5-, 1-, 2-, and 3-week nonsevere probabilities for patients with COVID-19 in the developing set. Each selected variable is represented by a line in the figure. According to the value, each variable receives 1 point. The total points are added for each variable and matched with the probability of COVID-19 progression.

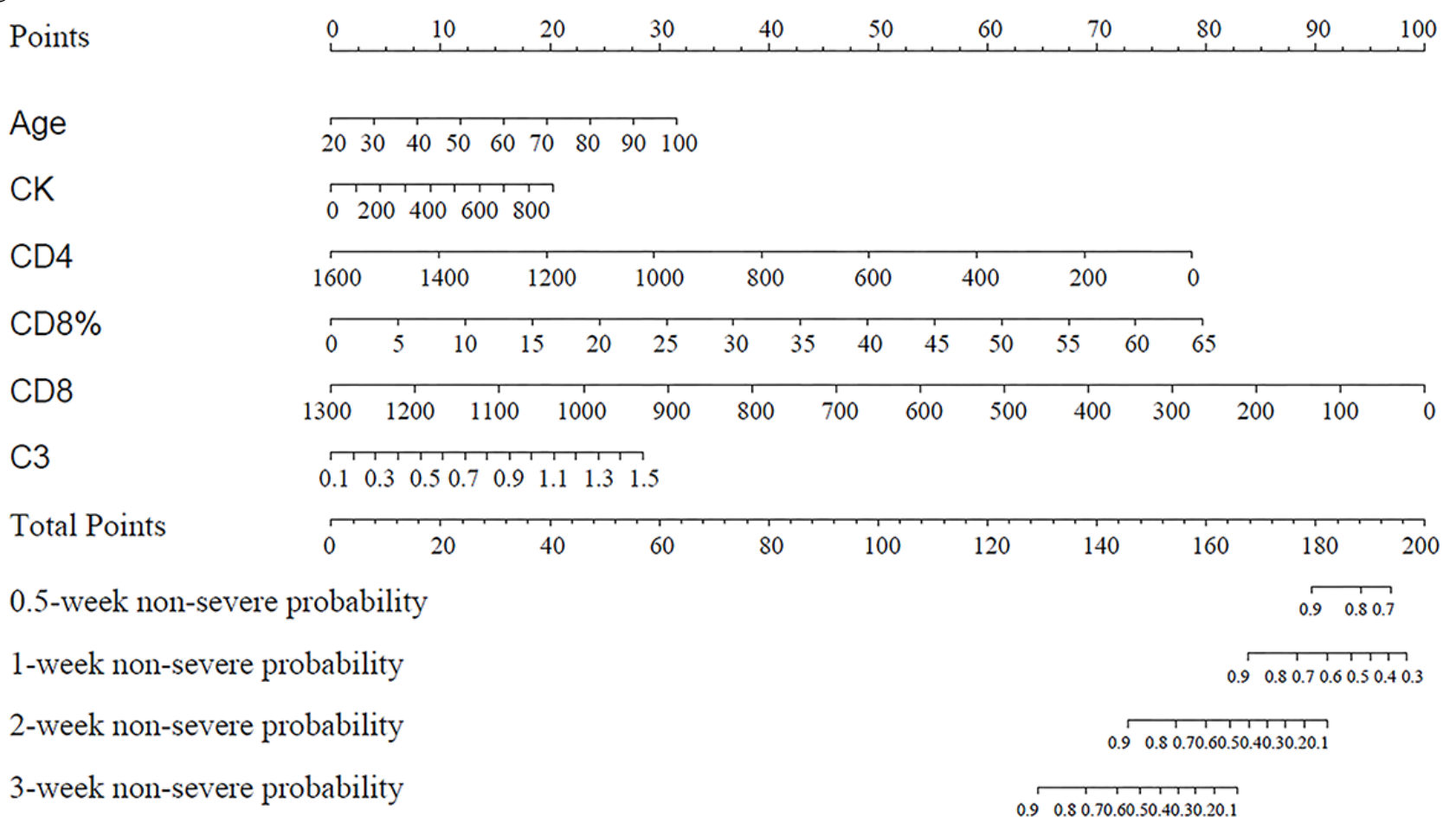

\section{Discussion}

\section{Principal Results}

In this report, we found that age, $\mathrm{CK}$ level, CD4 count, $\mathrm{CD} 8$ count, $\mathrm{CD} 8 \%$, and $\mathrm{C} 3$ count were the independent risk factors for the progression of COVID-19. In addition, we established a nomogram based on the six independent risk factors to predict the probability of $0.5-, 1-, 2-$, and 3-week nonsevere probability.

Since the first case of unexplained pneumonia was reported in the city of Wuhan [15], the disease has spread rapidly worldwide $[16,17]$. COVID-19 was recognized by the WHO as an international emergency public health event [18]. Current epidemiological studies have shown that the most common symptom of patients with COVID-19 before and after consultation is fever $[9,15,19]$. In this study, fever was identified in $123 / 175$ patients $(70.3 \%)$ when they were hospitalized. A total of $76 / 175$ participants in this study (43.4\%) were severely or critically ill, which accounts for the much higher rate of severity than that reported by Guan et al [19]. This may be due to the insufficient number of hospital beds and the fact that patients with severe conditions were preferentially admitted. Although the fatality rate of SARS-CoV-2 appears to be lower than that of SARS-CoV or MERS-CoV, the outcomes of SARS-CoV-2 patients are worse once the disease enters the severe stage. A retrospective study showed a $61.5 \%$ mortality rate in patients with severe COVID-19 [20]. If patients with high risk factors to progress to severe or critical illness can be screened out in a timely fashion for early intervention, the proportion of severe or critically ill patients and their mortality may be reduced significantly.
In this study, 175 patients were divided into a Mild group (patients with mild and moderate illness) and a Severe group (patients with severe and critical illness). A total of 33 variables were included in this study, including age and clinical laboratory parameters. Indices including age, CD4 count, CD8 count, CD8 $\%, \mathrm{C} 3$ count, and CK level were filtered out using LASSO and multivariate Cox regression. The indices were considered to be independent risk factors that affect COVID-19 progression. It was reported in a study involving 1099 COVID-19 patients that severe patients were typically seven years older than nonsevere patients (median) and that older patients with COVID-19 were more likely to progress to severe illness [19]. Research has shown that $\mathrm{T}$ cells are reduced and eventually fail in COVID-19 patients [21]. The results of this study are similar to the two findings mentioned above.

Because no specific medicine or vaccine has been made available for the treatment of SARS-CoV-2 infection to date [22], it is necessary to predict independent risk factors for the early detection of potential patients with severe COVID-19 and provide early intervention. Based on this research, age, myocardial function, and immune system and complement system function are key factors that impact COVID-19 progression. This study presents a nomogram that may be helpful to clinical physicians. Early intervention and supportive treatment for patients whose age and CK, CD4, CD8 and C3 values are in high-risk ranges may have important significance in reducing the severity and mortality of COVID- 19 .

\section{Limitations}

This study has some limitations. First, only 175 cases were included in the construction of the model that was used to screen for independent risk factors. Second, this is an observational 
study; therefore, it cannot directly lead to causal conclusions. Third, some patients had severe underlying diseases before becoming infected with the virus; therefore, there may be bias in the calculation of the nonsevere patients' survival times.

\section{Conclusions}

The COVID-19 outbreak quickly spread worldwide after it was first discovered in Wuhan. Currently, no specific medicine is available for the treatment of SARS-CoV-2 infection. It is necessary to establish a new predictive model that can be used to screen potential critical patients and provide early intervention. We presented a nomogram, compiled through the use of LASSO regression and multivariate Cox regression, which considers various clinical risk factors in evaluating the probability of COVID-19 progression. This nomogram may help clinical physicians prevent COVID-19 progression.

\section{Acknowledgments}

We thank all the patients involved in the study and their families. We thank all the authors for their contributions. This work was supported by the National Natural Science Foundation of China (81770095, 81700093).

\section{Authors' Contributions}

TF, ZL, RX, XS, and QG collected the data. TF, BH, BS, SY, ZH, and QG analyzed the data. TF, SY, and QG wrote the manuscript. $\mathrm{TF}, \mathrm{BH}$, and QG contributed to the figures. WJ, LZ, DL, RH, HM, WL, HF, and QG contributed to the interpretation of the data.

\section{Conflicts of Interest}

None declared.

\section{Multimedia Appendix 1}

Univariate Cox regression for independent risk factors in COVID-19 progression.

[DOC File, 47 KB-Multimedia Appendix 1]

\section{Multimedia Appendix 2}

Multivariate Cox regression for independent risk factors in COVID-19 progression.

[DOC File, 39 KB-Multimedia Appendix 2]

\section{Multimedia Appendix 3}

Instructions for using the nomogram.

[DOC File, 89 KB-Multimedia Appendix 3]

\section{Multimedia Appendix 4}

Calibration curves for evaluating the predictive performance of nomogram.

[PNG File, 265 KB-Multimedia Appendix 4]

\section{Multimedia Appendix 5}

Receiver operating characteristic curves for evaluating the predictive performance of the nomogram.

[PNG File, 138 KB-Multimedia Appendix 5]

\section{References}

1. Li Q, Guan X, Wu P, Wang X, Zhou L, Tong Y, et al. Early Transmission Dynamics in Wuhan, China, of Novel Coronavirus-Infected Pneumonia. N Engl J Med 2020 Mar 26;382(13):1199-1207 [FREE Full text] [doi:

10.1056/NEJMoa2001316] [Medline: 31995857]

2. Bao Y, Sun Y, Meng S, Shi J, Lu L. 2019-nCoV epidemic: address mental health care to empower society. Lancet 2020 Feb 22;395(10224):e37-e38 [ [FREE Full text] [doi: 10.1016/S0140-6736(20)30309-3] [Medline: 32043982]

3. Huang C, Wang Y, Li X, Ren L, Zhao J, Hu Y, et al. Clinical features of patients infected with 2019 novel coronavirus in Wuhan, China. Lancet 2020 Feb 15;395(10223):497-506 [FREE Full text] [doi: 10.1016/S0140-6736(20)30183-5] [Medline: 31986264]

4. Paules CI, Marston HD, Fauci AS. Coronavirus Infections-More Than Just the Common Cold. JAMA 2020 Jan 23;323(8):707-708. [doi: 10.1001/jama.2020.0757] [Medline: 31971553]

5. Parry J. Wuhan: Britons to be evacuated as scientists estimate 44000 cases of $2019-\mathrm{nCOV}$ in the city. BMJ 2020 Jan 29;368:m351. [doi: 10.1136/bmj.m351] [Medline: $\underline{\text { 31996342] }}$ 
6. Ohannessian R, Duong TA, Odone A. Global Telemedicine Implementation and Integration Within Health Systems to Fight the COVID-19 Pandemic: A Call to Action. JMIR Public Health Surveill 2020 Apr 02;6(2):e18810 [FREE Full text] [doi: 10.2196/18810] [Medline: 32238336]

7. Liao Q, Yuan J, Dong M, Yang L, Fielding R, Lam WWT. Public Engagement and Government Responsiveness in the Communications About COVID-19 During the Early Epidemic Stage in China: Infodemiology Study on Social Media Data. J Med Internet Res 2020 May 26;22(5):e18796 [FREE Full text] [doi: 10.2196/18796] [Medline: 32412414]

8. Sesagiri Raamkumar A, Tan SG, Wee HL. Measuring the Outreach Efforts of Public Health Authorities and the Public Response on Facebook During the COVID-19 Pandemic in Early 2020: Cross-Country Comparison. J Med Internet Res 2020 May 19;22(5):e19334 [FREE Full text] [doi: 10.2196/19334] [Medline: $\underline{\text { 32401219] }}$

9. Wang D, Hu B, Hu C, Zhu F, Liu X, Zhang J, et al. Clinical Characteristics of 138 Hospitalized Patients With 2019 Novel Coronavirus-Infected Pneumonia in Wuhan, China. JAMA 2020 Feb 07;323(11):1061-1069 [FREE Full text] [doi: 10.1001/jama.2020.1585] [Medline: $\underline{32031570]}$

10. Wu JT, Leung K, Leung GM. Nowcasting and forecasting the potential domestic and international spread of the 2019-nCoV outbreak originating in Wuhan, China: a modelling study. Lancet 2020 Feb 29;395(10225):689-697 [FREE Full text] [doi: 10.1016/S0140-6736(20)30260-9] [Medline: 32014114]

11. Phan LT, Nguyen TV, Luong QC, Nguyen TV, Nguyen HT, Le HQ, et al. Importation and Human-to-Human Transmission of a Novel Coronavirus in Vietnam. N Engl J Med 2020 Feb 27;382(9):872-874 [FREE Full text] [doi: 10.1056/NEJMc2001272] [Medline: 31991079]

12. Mo P, Xing Y, Xiao Y, Deng L, Zhao Q, Wang H, et al. Clinical characteristics of refractory COVID-19 pneumonia in Wuhan, China. Clin Infect Dis 2020 Mar 16:3725 [FREE Full text] [doi: 10.1093/cid/ciaa270] [Medline: $\underline{32173725]}$

13. Han Q, Lin Q, Jin S, You L. Coronavirus 2019-nCoV: A brief perspective from the front line. J Infect 2020 Apr;80(4):373-377 [FREE Full text] [doi: 10.1016/j.jinf.2020.02.010] [Medline: 32109444]

14. Clinical management of severe acute respiratory infection when novel coronavirus (nCoV) infection is suspected: interim guidance. World Health Organization. 2020 Jan 28. URL: https://apps.who.int/iris/handle/10665/330893 [accessed 2020-01-31]

15. Young BE, Ong SWX, Kalimuddin S, Low JG, Tan SY, Loh J, Singapore 2019 Novel Coronavirus Outbreak Research Team. Epidemiologic Features and Clinical Course of Patients Infected With SARS-CoV-2 in Singapore. JAMA 2020 Mar 03;323(15):1488-1494 [FREE Full text] [doi: 10.1001/jama.2020.3204] [Medline: 32125362]

16. Jernigan DB, CDC COVID-19 Response Team. Update: Public Health Response to the Coronavirus Disease 2019 Outbreak - United States, February 24, 2020. MMWR Morb Mortal Wkly Rep 2020 Feb 28;69(8):216-219 [FREE Full text] [doi: 10.15585/mmwr.mm6908e1] [Medline: 32106216]

17. Kraemer MUG, Yang C, Gutierrez B, Wu C, Klein B, Pigott DM, Open COVID-19 Data Working Group, et al. The effect of human mobility and control measures on the COVID-19 epidemic in China. Science 2020 May 01;368(6490):493-497 [FREE Full text] [doi: 10.1126/science.abb4218] [Medline: 32213647]

18. Coronavirus disease (COVID-19) pandemic. World Health Organization. URL: https://www.who.int/emergencies/diseases/ novel-coronavirus-2019 [accessed 2020-03-11]

19. Guan W, Ni Z, Hu Y, Liang W, Ou C, He J, China Medical Treatment Expert Group for Covid-19. Clinical Characteristics of Coronavirus Disease 2019 in China. N Engl J Med 2020 Apr 30;382(18):1708-1720 [FREE Full text] [doi: 10.1056/NEJMoa2002032] [Medline: 32109013]

20. Yang X, Yu Y, Xu J, Shu H, Xia J, Liu H, et al. Clinical course and outcomes of critically ill patients with SARS-CoV-2 pneumonia in Wuhan, China: a single-centered, retrospective, observational study. Lancet Respir Med 2020 May;8(5):475-481 [FREE Full text] [doi: 10.1016/S2213-2600(20)30079-5] [Medline: 32105632]

21. Ling Y, Xu S, Lin Y, Tian D, Zhu Z, Dai F, et al. Persistence and clearance of viral RNA in 2019 novel coronavirus disease rehabilitation patients. Chin Med J (Engl) 2020 May 05;133(9):1039-1043 [FREE Full text] [doi: 10.1097/CM9.0000000000000774] [Medline: 32118639]

22. de Wit E, van Doremalen N, Falzarano D, Munster VJ. SARS and MERS: recent insights into emerging coronaviruses. Nat Rev Microbiol 2016 Aug;14(8):523-534 [FREE Full text] [doi: 10.1038/nrmicro.2016.81] [Medline: 27344959]

\section{Abbreviations}

CK: creatine kinase

LASSO: least absolute shrinkage and selection operator

MERS-CoV: Middle East respiratory syndrome coronavirus

NHCPRC: National Health Commission of the People's Republic of China

OR: odds ratio

ROC: receiver operating characteristic

RT-PCR: reverse transcriptase-polymerase chain reaction

SARS-CoV: severe acute respiratory syndrome coronavirus

WHO: World Health Organization 


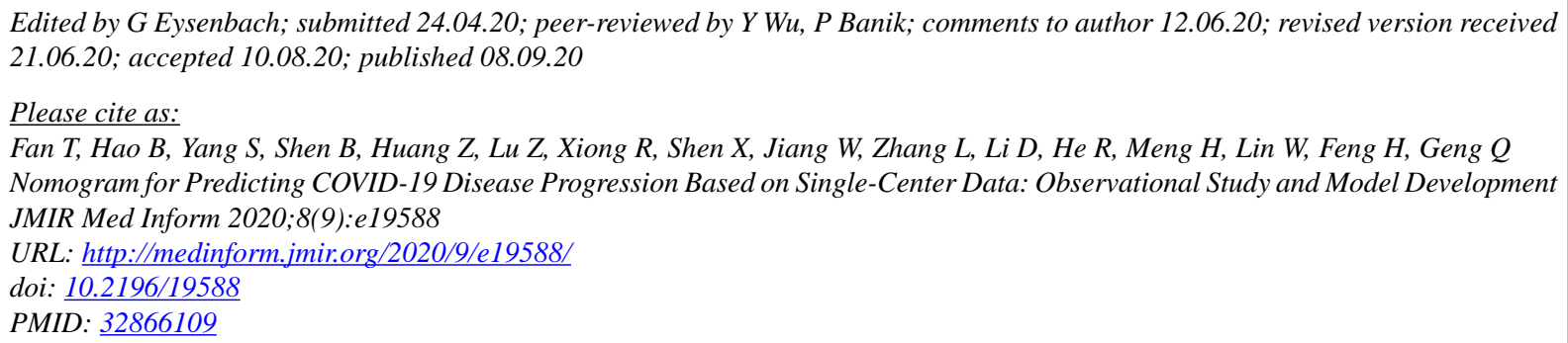

(CTao Fan, Bo Hao, Shuo Yang, Bo Shen, Zhixin Huang, Zilong Lu, Rui Xiong, Xiaokang Shen, Wenyang Jiang, Lin Zhang, Donghang Li, Ruyuan He, Heng Meng, Weichen Lin, Haojie Feng, Qing Geng. Originally published in JMIR Medical Informatics (http://medinform.jmir.org), 08.09.2020. This is an open-access article distributed under the terms of the Creative Commons Attribution License (https://creativecommons.org/licenses/by/4.0/), which permits unrestricted use, distribution, and reproduction in any medium, provided the original work, first published in JMIR Medical Informatics, is properly cited. The complete bibliographic information, a link to the original publication on http://medinform.jmir.org/, as well as this copyright and license information must be included. 